\title{
Article \\ Boriding of Laser-Clad Inconel 718 Coatings for Enhanced Wear Resistance
}

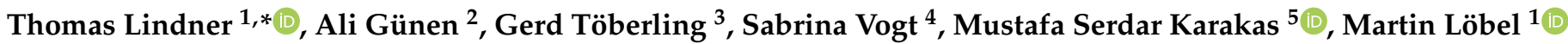 \\ and Thomas Lampke ${ }^{1}$ (D)
}

Citation: Lindner, T.; Günen, A.;

Töberling, G.; Vogt, S.; Karakas, M.S.; Löbel, M.; Lampke, T. Boriding of Laser-Clad Inconel 718 Coatings for Enhanced Wear Resistance. Appl. Sci. 2021, 11, 11935. https://doi.org/ 10.3390/app112411935

Academic Editor:

Tomasz Chmielewski

Received: 18 November 2021

Accepted: 13 December 2021

Published: 15 December 2021

Publisher's Note: MDPI stays neutral with regard to jurisdictional claims in published maps and institutional affiliations.

Copyright: (c) 2021 by the authors. Licensee MDPI, Basel, Switzerland. This article is an open access article distributed under the terms and conditions of the Creative Commons Attribution (CC BY) license (https:// creativecommons.org/licenses/by/ $4.0 /)$.
1 Materials and Surface Engineering Group, Institute of Materials Science and Engineering, Chemnitz University of Technology, 09107 Chemnitz, Germany; martin.loebel.ww@gmail.com (M.L.); thomas.lampke@mb.tu-chemnitz.de (T.L.)

2 Department of Metallurgy and Materials Engineering, Faculty of Engineering and Natural Sciences, Iskenderun Technical University, Iskenderun 31200, Turkey; ali.gunen@iste.edu.tr

3 Fraunhofer Institute for Machine Tools and Forming Technology IWU, 09126 Chemnitz, Germany; Gerd.Toeberling@iwu.fraunhofer.de

4 TRUMPF Laser- und Systemtechnik GmbH, 71254 Ditzingen, Germany; sabrina.vogt@trumpf.com

5 Department of Metallurgical and Materials Engineering, Faculty of Engineering and Natural Sciences, Konya Technical University, Konya 42250, Turkey; mskarakas@ktun.edu.tr

* Correspondence: th.lindner@mb.tu-chemnitz.de

\begin{abstract}
Nickel-based superalloys are particularly suitable for applications under corrosive conditions. Economic advantages can be achieved by limiting the use of materials to the surface region. Furthermore, the tribological property profile can be significantly improved by surface hardening. In the present study, the possibility of a process combination comprising a coating and a surface hardening technology was investigated. For this purpose, Inconel 718 coatings were applied to austenitic stainless steel by laser cladding. Subsequently, a thermochemical surface hardening by boriding was carried out. Scanning electron microscopic (SEM) examinations were performed to evaluate the microstructure. The phase composition was determined by means of $\mathrm{X}$-ray diffraction (XRD) for the different states of the coating system. The influence of thermochemical hardening was investigated for different wear conditions. The increase in microhardness and wear resistance clearly demonstrates the utilization potential of the presented process combination.
\end{abstract}

Keywords: Inconel 718; IN718; laser cladding; laser-clad; boriding; boronizing; hardening; wear

\section{Introduction}

Nickel-based superalloys are high-performance materials with a unique property profile [1-8]. The high material costs only justify their use where alternative material concepts cannot offer a sufficient service life or protection. Coating technologies enable an economical alternative to traditional monolithic materials. Laser cladding as a coating process is particularly suitable for such a purpose [4,9-11]. By creating a metallurgical bond between the cladding and the substrate, high adhesive strengths can be achieved. In addition, a compact coating structure is produced, which reliably protects the substrate material from corrosive attack. However, nickel-based superalloys are prone to tribological attack due to their ductile matrix [7,8,12-17]. Inconel 718 is widely used as feedstock material. The tribological properties of laser-clad coatings have already been investigated by several groups $[18,19]$. For a corrosive and tribological load collective, adaptive solution concepts are necessary for the component surface. In the field of functionalization of structural materials, thermochemical surface hardening methods have become well established. Compared to alternative processes, boriding offers the highest achievable values with regard to surface hardness and wear resistance [20-29]. The process variant of powder-pack boriding is particularly suitable for this purpose [23-31]. An adapted process routine allows for homogeneous surface layers to be formed without silicidation in the 
case of nickel-based alloys. A process combination consisting of a coating step, as well as surface layer hardening, can provide economic advantages, especially in comparison to monolithic component design. Such a process combination is currently unexplored in the case of laser-clad, nickel-based superalloys.

However, a series of studies on the thermochemical surface hardening of coating systems have proven the fundamental feasibility of this process combination. Initial investigations were carried out on high-velocity oxy-fuel (HVOF) and plasma-sprayed AISI 316L coating systems [32,33]. Further investigations on the surface hardening of cold gas sprayed coatings confirmed the results $[34,35]$. By carburizing, nitriding, and nitrocarburizing at low process temperatures, the formation of an expanded austenitic phase could be achieved. This has led to a significant increase in wear resistance [32-38]. Investigations on plasma nitriding of austenitic layers produced by direct laser metal deposition and laser powder-bed fusion could also confirm the improvement potential $[39,40]$. First investigations on the thermochemical surface hardening of powder feedstock materials for coating processes were carried out [41]. In addition to the methods for interstitial surface hardening, various possibilities of precipitation hardening by nitriding were also considered [38]. In comparison to solid solution hardening, a different diffusion behavior was demonstrated. First investigations showed the suitability of a powder-pack boriding treatment for improving the wear resistance of thermally sprayed coating systems [42,43]. Laser cladding causes a higher thermal load on the substrate material compared to thermal spraying. Nevertheless, laser-clad coatings are characterized by a higher corrosion resistance due to their compact structure.

In the present study, the concept of a process combination consisting of a coating step by laser cladding and subsequent surface hardening by boriding was investigated using the alloy Inconel 718. The conducted feasibility study clearly showed the potential of such a process combination.

\section{Materials and Methods}

For the experimental procedure, a gas atomized Inconel 718 powder (Praxair NI-202-3) with a particle size of $\mathrm{d} 90=45 \mu \mathrm{m}$ and $\mathrm{d} 10=16 \mu \mathrm{m}$ was used. The coating was applied to a round blank of grade AISI 316L with a thickness of $6 \mathrm{~mm}$ and a diameter of $100 \mathrm{~mm}$. Prior to the coating process, the blanks were cleaned with alcohol. The coating was performed with a high-speed laser cladding system, consisting of a TRUMPF BEO D70 Optic, which was equipped with the prototype of a TRUMPF 7-ray nozzle, and a TRUMPF TruDisk 6001 laser source. The powder was fed during the deposition process using a plate feeder. The feed rate, which results from the path velocity and the trace offset, was controlled by the axial rotation of a conventional industrial robot. The synchronization of both systems by the robot controller allowed for the implementation of a constant feed rate depending on the diameter during the entire coating process. The processing of the powder was carried out according to the parameters stated in Table 1.

Table 1. Laser cladding parameters for Inconel 718.

$\begin{array}{cc}\text { power }(\mathrm{W}) & 4000 \\ \text { Spotsize }(\mathrm{mm}) & 1.8 \\ \text { path velocity }\left(\mathrm{m} \cdot \mathrm{s}^{-1}\right) & 0.42 \\ \text { trace offset }(\mathrm{mm}) & 0.3 \\ \text { overlap }(\%) & 83 \\ \text { feeding rate }\left(\mathrm{g} \cdot \mathrm{min}^{-1}\right) & 35 \\ \text { Ar gas flow rate }\left(\mathrm{L} \cdot \mathrm{min}^{-1}\right) & 12 \\ \text { No. of passes } & 1\end{array}$

In order to remove the surface roughness, a grinding treatment and subsequent polishing were performed according to standard metallographic procedures. The thermochemical treatment by powder-pack boriding was carried out using a process routine developed for 
nickel alloys. In the present study, $50-100 \mathrm{~nm} \mathrm{~B}_{4} \mathrm{C}$ powders were chosen, since boronizing powder mixtures often allow for boronizing to be achieved in a shorter time for the same boronizing temperature compared to micron-sized powders [44]. The process parameters are shown in Table 2.

Table 2. Powder-pack boriding parameters for Inconel 718.

$\begin{array}{cc}\text { boriding agent } & 90 \mathrm{wt} \% \mathrm{~B}_{4} \mathrm{C}+10 \mathrm{wt} \% \mathrm{NaBF}_{4} \\ \text { temperature } & 900{ }^{\circ} \mathrm{C} \\ \text { duration } & 2 \mathrm{~h}, 8 \mathrm{~h} \\ \text { atmosphere } & \mathrm{Ar}\end{array}$

The feedstock powder and the laser-clad coatings were subjected to $\mathrm{X}$-ray fluorescence (XRF) analysis in a Fischerscope X-ray XAN device (Helmut Fischer, Sindelfingen, Germany) to determine the chemical composition in three comparative measurements. An acceleration voltage of $30 \mathrm{kV}$, a current of $1 \mathrm{~mA}$, a Ni primary filter, and a collimator diameter of $0.6 \mathrm{~mm}$ were applied.

Metallographic cross-sections of the coating were prepared according to a metallographic standard routine. Etching was performed using a solution consisting of $50 \mathrm{~mL} \mathrm{HCl}$ and $150 \mathrm{~mL} \mathrm{HNO}_{3}$ with an etching time of $15 \mathrm{~s}$. The microstructure of the coating was investigated by scanning electron microscopy (SEM) using an LEO 1455VP (Zeiss, Oberkochen, Germany) microscope. The morphology, microstructure, and chemical composition were investigated by means of secondary and backscattered electron imaging.

A surface microhardness measurement was carried out by nanoindentation. For this, a Fischerscope HM 2000 XYp (Helmut Fischer GmbH, Sindelfingen, Germany) with a Vickers tip was used for progressive measurement with a load of $10 \mathrm{mN}$. Borosilicate glass BK7 was used as the calibration standard. At least ten single measurements were considered for the calculation of the average microhardness and the standard deviation.

Crystallographic studies were carried out by XRD measurements using a D8 DISCOVER diffractometer from the Bruker Corporation (Billerica, MA, USA). Monochromatic $\mathrm{Co}-\mathrm{K} \alpha \mathrm{X}$-ray radiation was utilized for all measurements. A voltage of $40 \mathrm{kV}$, a current of $40 \mathrm{~mA}$, a sampling rate of $24^{\circ} \mathrm{h}^{-1}$, and a diffraction angle range of $20^{\circ}$ to $130^{\circ}$ was used. The X-ray sensor used was a LynxEye-XE detector, the aperture size after the beam gun was $2 \mathrm{~mm}$, and a polycap was used to obtain a parallel beam emission. The data was evaluated using Rietveld refinement. Elemental analyses of the borided layers with depth resolution were performed by glow discharge spectroscopy (GDOS) with a GDA 750 (SpectrumaAnalytik GmbH, Hof, Germany). For the measurements, a $2.5 \mathrm{~mm}$ anode, operating under $800 \mathrm{~V}$, and $25 \mathrm{~mA}$ under $3 \mathrm{hPa}$ Ar pressure were used.

Furthermore, detailed studies to determine the influence on the tribological properties were conducted. The sliding wear behavior was investigated utilizing a ball-on-disk test, using the Tetra basalt tester (Tetra, Ilmenau, Germany). For the investigation of the wear behavior under reciprocating conditions, a Wazau SVT 40 device (Wazau, Berlin, Germany) was used. The wear test parameters are summarized in Table 3.

Table 3. Wear test parameters.

\begin{tabular}{cccc}
\hline \multicolumn{2}{c}{ Ball-On-Disk Test } & \multicolumn{2}{c}{ Reciprocating Wear Test } \\
\hline force & $20 \mathrm{~N}$ & force & $26 \mathrm{~N}$ \\
radius & $5 \mathrm{~mm}$ & frequency & $40 \mathrm{~Hz}$ \\
speed & $96 \mathrm{RPM}$ & time & $900 \mathrm{~s}$ \\
cycles & 15,916 & amplitude & $0.5 \mathrm{~mm}$ \\
counter-body & $\mathrm{Al}_{2} \mathrm{O}_{3}(\varnothing 6 \mathrm{~mm})$ & counter-body & $\mathrm{Al}_{2} \mathrm{O}_{3}(\varnothing 10 \mathrm{~mm})$ \\
\hline
\end{tabular}

The wear depth of the ball-on-disk test was determined by tactile measurements utilizing a Hommel-Etamic T8000 device (Jenoptik, Villingen-Schwenningen, Germany). 
For the evaluation of the reciprocating wear tests, a Keyence VK-X200 laser scanning microscope (Keyence, Osaka, Japan) was used.

\section{Results}

The chemical composition was determined for the feedstock powder, as well as the coating in the as-clad state, the as-ground state, and both borided states by XRF spectrometry. Five measurements were conducted for each state. The normalized values of the main alloying elements are shown in Table 4.

Table 4. Chemical composition measured by XRF, in wt $\%$.

\begin{tabular}{ccccccc}
\hline Sample & $\mathbf{N i}$ & $\mathbf{C r}$ & $\mathbf{F e}$ & $\mathbf{N b}$ & $\mathbf{M o}$ & $\mathbf{T i}$ \\
\hline feedstock powder & 53.1 & 19.1 & 18.5 & 5.1 & 3.3 & 0.9 \\
coating (as-clad) & 53.4 & 19.5 & 19.0 & 4.4 & 2.7 & 1.0 \\
coating (polished) & 53.8 & 19.0 & 18.9 & 4.5 & 3.0 & 0.8 \\
coating borided 2 h & 58.4 & 15.5 & 18.1 & 4.4 & 2.9 & 0.6 \\
coating borided 8 h & 68.0 & 9.7 & 15.2 & 4.2 & 2.7 & 0.2 \\
coating 50 $\mu$ m above substrate & 53.8 & 19.1 & 18.9 & 4.6 & 2.7 & 0.9 \\
\hline
\end{tabular}

The results of the XRF measurement reveal a good correlation between the chemical composition of the Inconel 718 powder feedstock and the coating system. This consistency, which was already achieved in the as-clad state, confirms the process quality. The results could be confirmed in the polished condition. XRF measurements within GDOS calottes demonstrated an excellent agreement of the chemical composition to the polished state. This confirmed a homogeneous chemical composition without elemental gradations over almost the entire coating thickness. Consequently, mixing between the substrate and coating material, as well as the vaporization of constituents, was largely prevented. Due to diffusion enrichment with boron, the ratios of the alloying elements in the immediate surface area shifted in relation to each other. Nickel increased significantly with the increasing treatment time compared to chromium and iron. The average thickness of the coating was approximately $500 \mu \mathrm{m}$. After mechanical finishing, the thickness was reduced to about $230 \mu \mathrm{m}$. The transition zone was crack-free and ensured good metallurgical bonding. Limited intermixing appeared only within the immediate interfacial area.

After laser cladding, thermochemical boriding treatments were carried out. Figure 1a,b shows exemplary SEM images of the coating after boriding using backscattered electron imaging. Despite the deviation from the intended composition, a homogeneous precipitation layer formed for both states. The thickness of the boride layer after a treatment of $2 \mathrm{~h}$ is at least $22 \mu \mathrm{m}$. No cracks, pores, or other structural defects were visible. The smooth transition from the boride layer to the Inconel 718 cladding ensured strong adhesion between the two layers. Thermochemical diffusion coatings often provide better adhesion with the substrate compared to faster coating application techniques, such as thermal spray coating [45]. At an increased boriding duration of $8 \mathrm{~h}$, an increase in diffusion depth to almost $65 \mu \mathrm{m}$ was observed. Additionally, irregularities were detected on the surface, which increased with the duration of the boriding treatment. Three areas could be distinguished in the cross-sectional microstructures. The topmost double-phase boride layer displayed a homogeneous structure. The diffusion zone underneath the boride layer exhibited an irregular morphology and contained grain-boundary precipitates. The precipitates extended far along the grain boundaries until they reached the core of the Inconel 718 cladding, which was unaffected by the diffusion of the boron. 


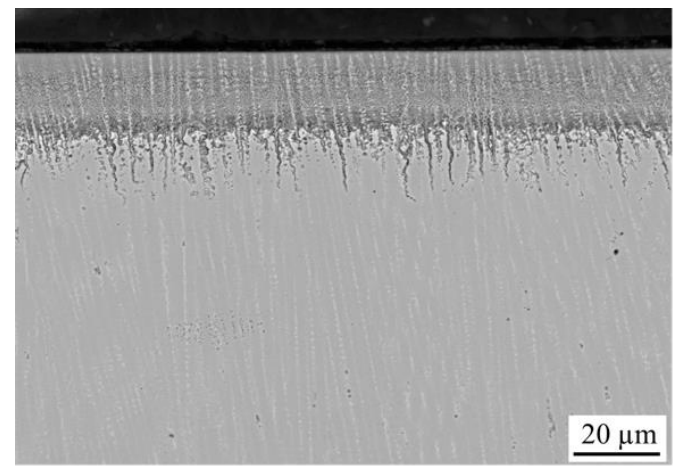

(a)

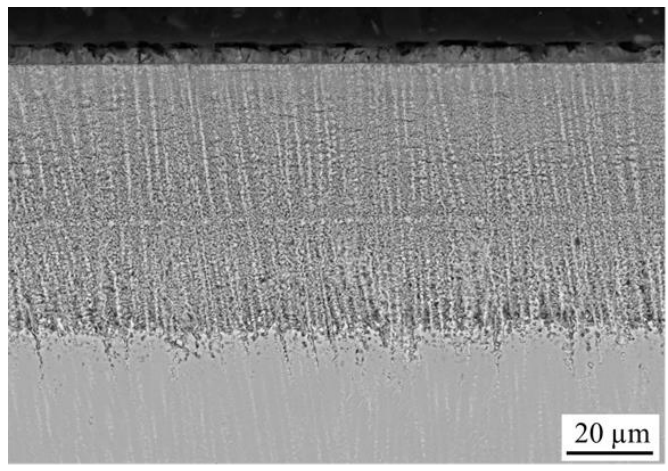

(b)

Figure 1. Microstructural SEM cross section images (BSD) of the laser-clad coating of Inconel 718 for a boriding duration of (a) $2 \mathrm{~h}$ and (b) $8 \mathrm{~h}$.

In order to identify the elemental distribution within the boride layer and the diffusion zone, GDOS measurements were carried out. The results of the qualitative analyses are shown in Figure 2. Depending on boriding time, a constant plateau for boron intensity was observed, which is characteristic of the boride layer. Beyond a certain depth, the boron intensity decreased abruptly. This corresponded to the diffusion zone containing the precipitates as detected in the SEM. In the immediate surface, increased nickel intensities could be detected, especially in the case of the $8 \mathrm{~h}$ boriding treatment. This result is in line with the results of the XRF measurements. However, within the borided layer, the gradient between the main alloying elements diminished. Independent of the treatment time, a simultaneous but gradual increase in the relative intensities of the main alloying elements was observed, starting from a depth of about $20 \mu \mathrm{m}$. The GDOS measurements complement the characterizations of the structure of the boride layer, which was also analyzed by SEM.

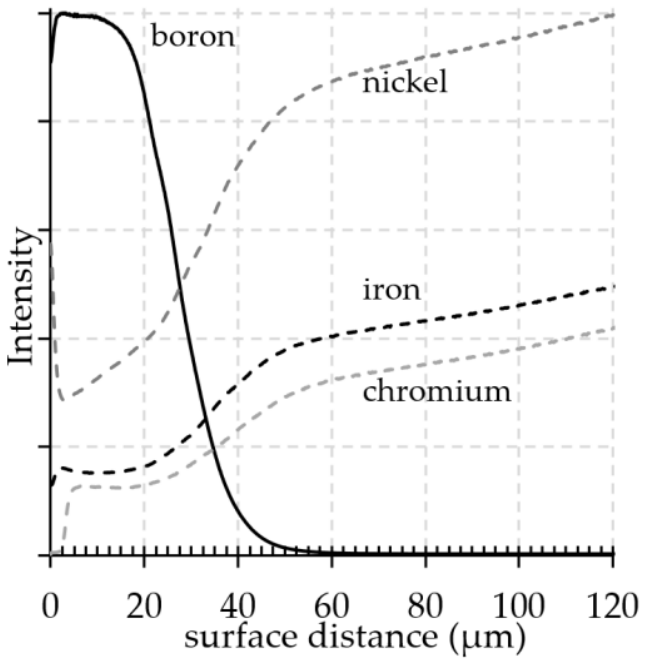

(a)

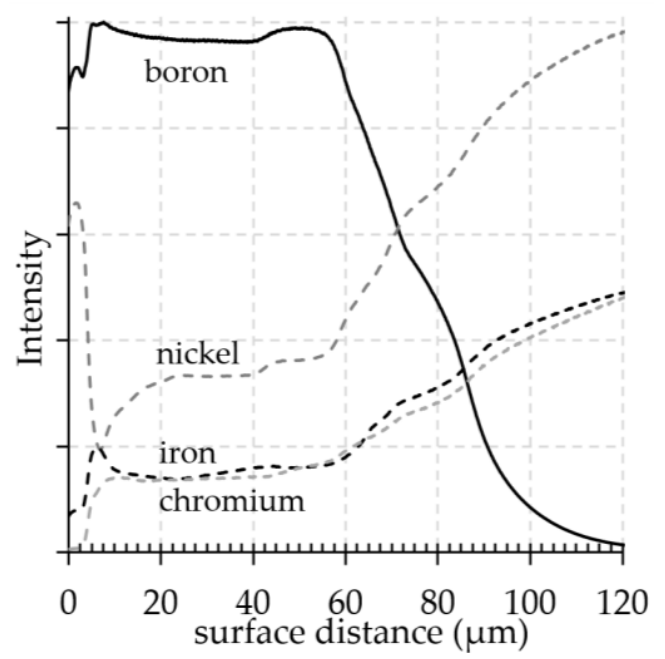

(b)

Figure 2. Elemental distribution within the diffusion layer of Inconel 718 laser-clad coatings measured by GDOS (a) $2 \mathrm{~h} \mathrm{(b)} 8 \mathrm{~h}$.

The phase composition was determined by XRD measurements. The diffraction patterns of the coatings are shown in Figure 3 as a function of boriding time. In the as-clad state, the coating exhibited a single-phase microstructure consisting of the gamma $(\gamma)$ phase with a face-centered cubic (fcc) crystal structure. Successful inert gas control in the process was confirmed by the absence of oxides on the surface. The results of the two borided samples confirmed the successful formation of a boride layer. $\mathrm{BNi}_{2}$ was detected as the 
main boride phase in both ( $2 \mathrm{~h}$ and $8 \mathrm{~h}$ ) cases. FeB could be detected as an additional phase and was detectable at significantly lower intensities for both treatment durations. With increasing boriding time, the intensity of the $\mathrm{BNi}_{2}$ phase increased significantly, which hinted at an increase in the boride layer thickness. The characteristic peaks of FeB occurred more intensely at higher angles for $8 \mathrm{~h}$ of treatment, indicating a high depth of detection.

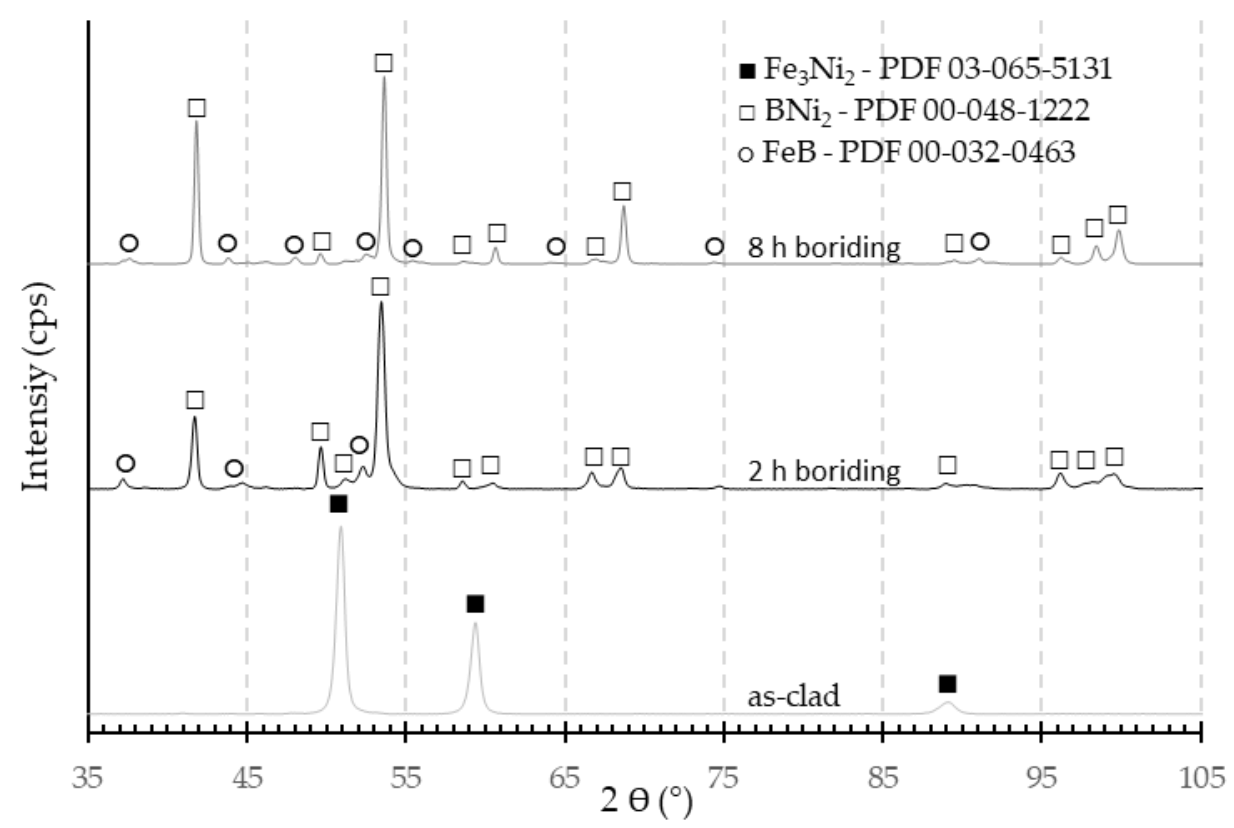

Figure 3. Diffractograms of Inconel 718 coating in as-clad and borided state.

A successful formation of a precipitation layer was possible by diffusion enrichment with boron. To investigate the influence of the treatment condition on the resulting properties, surface hardness measurements have been conducted. The results are summarized in Table 5. For both treatment regimes, the resulting hardness exceeded 1600 HV0.001 and was significantly higher than the reference hardness of Inconel 718 with 377 HV0.001. Although a higher average microhardness was determined for a longer duration of the thermochemical treatment, no clear trend can be derived due to the high standard deviation. The main reason for this was structural defects within the precipitation layer.

Table 5. Surface microhardness HV 0.001 of borided Inconel 718 laser-clad coatings.

\begin{tabular}{ccc}
\hline Untreated & Borid Layer $\mathbf{2} \mathbf{h}$ & Borid Layer $\mathbf{8} \mathbf{~ h}$ \\
\hline $377 \pm 35$ & $1628 \pm 352$ & $1708 \pm 375$ \\
\hline
\end{tabular}

The wear behavior was investigated using ball-on-disk and reciprocating ball-onplane tests. The results are summarized in Figure 4. Compared to the untreated condition, boriding significantly improved the wear resistance under both wear conditions. In the ball-on-disk test, the borided coating offered almost full protection under the test conditions used for sliding wear. Significant improvements could also be seen in the reciprocating wear test. The maximum wear depth of the borided coating was in the range of the thickness of the boride layer. 


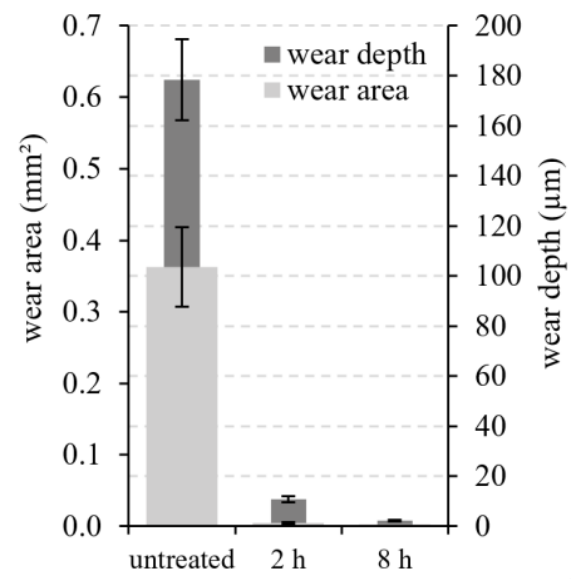

(a)

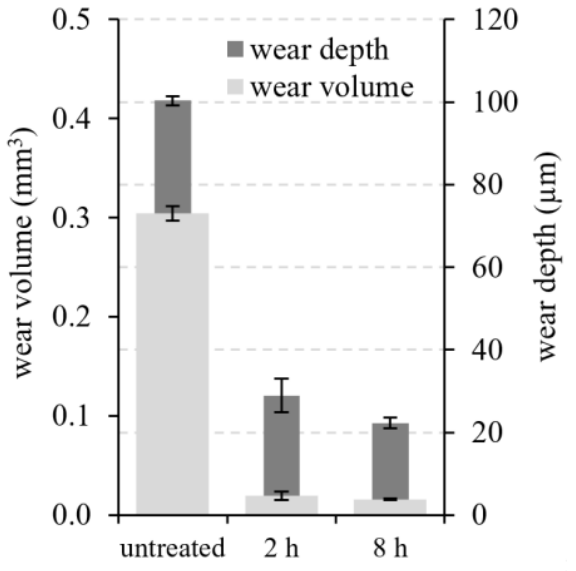

(b)

Figure 4. Results of wear investigations (a) ball-on-disk test and (b) reciprocating wear test.

\section{Conclusions}

A novel process combination involving the surface hardening of laser-clad Inconel 718 coatings by powder-pack boriding was investigated. The microstructural characteristics, as well as the elemental distribution within the borided surface layers and the tribological properties under different wear conditions, were compared. Despite the single pass in the coating process, XRF investigations have shown that mixing with the substrate material could be largely prevented. The composition of the coating surface also showed only slight deviations from the target composition, indicating low oxidation. Diffusion enrichment with boron resulted in enrichment with nickel in the surface layer region. For both $2 \mathrm{~h}$ and $8 \mathrm{~h}$ tests, the formation of a homogeneous and double-phase boride layer could be detected. The nickel-rich $\mathrm{BNi}_{2}$ phase showed the highest intensity. With increasing treatment time, an increase in diffusion depth could be detected. A significant increase in microhardness could be achieved by the thermochemical treatment. Compared with the untreated condition, this resulted in a significant increase in wear resistance under ball-on-disk and reciprocating wear conditions. The results confirm the great potential of the presented process combination of laser cladding and surface hardening.

Author Contributions: Conceptualization, T.L. (Thomas Lindner), A.G. and G.T.; methodology, T.L. (Thomas Lindner), A.G., G.T., S.V., M.S.K. and M.L.; validation and investigation, T.L. (Thomas Lindner), A.G. and G.T.; writing — original draft preparation, T.L. (Thomas Lindner); writing—review and editing and supervision, S.V., M.S.K. and T.L. (Thomas Lampke); project administration, T.L. (Thomas Lindner) and T.L. (Thomas Lampke); funding acquisition, T.L. (Thomas Lindner). All authors have read and agreed to the published version of the manuscript.

Funding: The APC was funded by Chemnitz University of Technology.

Institutional Review Board Statement: Not applicable.

Informed Consent Statement: Not applicable.

Data Availability Statement: Not applicable.

Acknowledgments: The support by Niclas Hanisch, Christian Loos, and Marc Pügner (all from the Institute of Materials Science and Engineering) is gratefully acknowledged.

Conflicts of Interest: The authors declare no conflict of interest.

\section{References}

1. Cwalina, K.L.; Demarest, C.R.; Gerard, A.Y.; Scully, J.R. Revisiting the effects of molybdenum and tungsten alloying on corrosion behavior of nickel-chromium alloys in aqueous corrosion. Curr. Opin. Solid State Mater. Sci. 2019, 23, 129-141. [CrossRef]

2. Osoba, L.; Oladoye, A.; Ogbonna, V.E. Corrosion evaluation of superalloys Haynes 282 and Inconel 718 in hydrochloric acid. J. Alloys Compd. 2019, 804, 376-384. [CrossRef] 
3. Wang, J.; Xu, J.; Zhang, X.; Ren, X.; Song, X.; Chen, X. An Investigation of Surface Corrosion Behavior of Inconel 718 after Robotic Belt Grinding. Materials 2018, 11, 2440. [CrossRef]

4. Abioye, T.; Mccartney, D.G.; Clare, A.T. Laser cladding of Inconel 625 Wire for Corrosion Protection. J. Mater. Process. Technol. 2014, 217, 232-240. [CrossRef]

5. $\quad$ Chen, T.C.; Chou, C.C.; Yung, T.Y.; Cai, R.F.; Huang, J.Y.; Yang, Y.C. A comparative study on the tribological behavior of various thermally sprayed Inconel 625 coatings in a saline solution and deionized water. Surf. Coat. Technol. 2020, 385, 125442. [CrossRef]

6. Yung, T.Y.; Chen, T.C.; Tsai, K.C.; Lu, W.F.; Huang, J.Y.; Liu, T.Y. Thermal Spray Coatings of Al, ZnAl and Inconel 625 Alloys on SS304L for Anti-Saline Corrosion. Coatings 2019, 9, 32. [CrossRef]

7. Petrova, R.S.; Suwattananont, N.; Samardzic, V. The Effect of Boronizing on Metallic Alloys for Automotive Applications. J. Mater. Eng. Perform. 2008, 17, 3. [CrossRef]

8. Kurzynowski, T.; Smolina, I.; Kobiela, K.; Kuźnicka, B.; Chlebus, E. Wear and corrosion behaviour of Inconel 718 laser surface alloyed with rhenium. Mater. Des. 2017, 132, 349-359. [CrossRef]

9. Feng, K.; Yuan, C.; Deng, P.; Li, Y.; Zhao, H.; Lu, F.; Li, R.; Huang, J.; Li, Z.G. Improved high-temperature hardness and wear resistance of Inconel 625 coatings fabricated by laser cladding. J. Mater. Process. Technol. 2016, 243, 82-91. [CrossRef]

10. Fesharakia, M.N.; Shoja-Razavib, R.; Mansouria, H.A.; Jamali, H. Evaluation of the hot corrosion behavior of Inconel 625 coatings on the Inconel 738 substrate by laser and TIG cladding techniques. Opt. Laser Technol. 2019, 111, 744-753. [CrossRef]

11. Zafer, Y.E.; Goel, S.; Ganvir, A.; Jansson, A.; Joshi, S.V. Encapsulation of Electron Beam Melting Produced Alloy 718 to Reduce Surface Connected Defects by Hot Isostatic Pressing. Materials 2020, 13, 1226. [CrossRef]

12. Xin, L.; Wang, Z.; Li, J.; Lu, Y.; Shoji, T. Microstructural characterization of subsurface caused by fretting wear of Inconel 690TT alloy. Mater. Charact. 2016, 115, 32-38. [CrossRef]

13. Rustamov, I.; Guo, F.; Wang, Z. Experimental investigations into fretting wear and damage mechanisms of Inconel X-750 alloy. J. Mech. Sci. Technol. 2019, 33, 4701-4713. [CrossRef]

14. Li, J.; Lu, Y.; Zhang, H.; Xin, L. Effect of grain size and hardness on fretting wear behavior of Inconel 600 alloys. Tribol. Int. 2015, 81, 215-222. [CrossRef]

15. Yun, J.Y.; Lee, H.S.; Hur, D.H.; Kang, W.S.; Bae, C.H.; Kim, S.J. Effect of oxidation film on the fretting wear behavior of Alloy 690 steam generator tube mated with SUS 409. Wear 2016, 368-369, 344-349. [CrossRef]

16. Li, J.; Ma, M.; Lu, Y.H.; Xin, L. Evolution of wear damage in Inconel 600 alloy due to fretting against type 304 stainless steel. Wear 2016, 346-347, 15-21. [CrossRef]

17. Guo, X.; Lai, P.; Tang, L.; Wang, J.; Zhang, L. Effects of sliding amplitude and normal load on the fretting wear behavior of alloy 690 tube exposed to high temperature water. Tribol. Int. 2017, 116, 155-163. [CrossRef]

18. Zhu, L.; Yang, Z.; Xin, B.; Wang, S.; Meng, G.; Ning, J.; Xue, P. Microstructure and mechanical properties of parts formed by ultrasonic vibration-assisted laser cladding of Inconel 718. Surf. Coat. Technol. 2021, 410, 126964. [CrossRef]

19. Zhang, Y.; Yang, L.; Dai, J.; Liu, J.; Zhang, W.; Chen, H.; Wang, Z.; Shi, K. Microstructure and mechanical properties of pulsed laser cladded IN718 alloy coating. Surf. Eng. 2018, 34, 259-266. [CrossRef]

20. Campos-Silva, I.; Contla-Pacheco, A.D.; Ruiz-Rios, A.; Martínez-Trinidad, J.; Rodriguez, G.; Amador, A.M.; Wong-Ángel, W.D. Effects of scratch tests on the adhesive and cohesive properties of borided Inconel 718 superalloy. Surf. Coat. Technol. 2018, 349, 917-927. [CrossRef]

21. Makuch, N.; Kulka, M.; Paczkowska, M. Nanomechanical properties of gas-borided layer produced on Nimonic 80A-alloy. Ceram. Int. 2017, 43, 11. [CrossRef]

22. Sista, V.; Kahvecioglu, O.; Sireli, G.K.; Zeng, Q.; Kim, J.H.; Eryilmaz, O.L.; Erdemir, A. Evaluation of electrochemical bonding of Inconel 600. Surf. Coat. Technol. 2013, 215, 452-459. [CrossRef]

23. Günen, A.; Kanca, E. Microstructure and Mechanical Properties of Borided Inconel 625 Superalloy. Matéria (Rio De Jan.) 2017, 22, e11829. [CrossRef]

24. Campos-Silva, I.; Contla-Pacheco, A.D.; Figueroa-López, U.; Ortega, M. Sliding wear resistance of nickel boride layers on an Inconel 718 superalloy. Surf. Coat. Technol. 2019, 378, 124862. [CrossRef]

25. Piasecki, A.; Kotkowiak, M.; Makuch, N.; Kulka, M. Wear behavior of self-lubricating boride layers produced on Inconel 600-alloy by laser alloying. Wear B 2019, 426-427, 919-933. [CrossRef]

26. Günen, A. Properties and High Temperature Dry Sliding Wear Behavior of Boronized Inconel 718. Metall. Mater. Trans. A 2020, 51, 927-939. [CrossRef]

27. Günen, A.; Erdoğan, K. Characterization of borided Inconel 625 alloy with different boron chemicals. Pamukkale Univ. Muh Bilim. Derg. 2017, 23, 411-416. [CrossRef]

28. Hunger, H.J.; Trute, G. Successful Boronizing of Nickel-Based Alloys. Mater. Sci. Forum 1994, 163-165, 341-346. [CrossRef]

29. Hunger, H.J.; Trute, G. Probleme beim Borieren von Ni-Basiswerkstoffen. Härterei-Tech. Mitt.-HTM 1994, 49, 215-218. [CrossRef]

30. Lindner, T.; Löbel, M.; Sattler, B.; Lampke, T. Surface Hardening of FCC phase High-Entropy Alloy System by Powder-Pack Boriding. Surf. Coat. Technol. 2019, 371, 389-394. [CrossRef]

31. Erdogan, A.; Günen, A.; Gök, M.S.; Zeytin, S. Microstructure and mechanical properties of borided $\mathrm{CoCrFeNiAl}_{0.25} \mathrm{Ti}_{0.5} \mathrm{high}$ entropy alloy produced by powder metallurgy. Vacuum 2020, 183, 109820. [CrossRef] 
32. Wielage, B.; Rupprecht, C.; Lindner, T.; Hunger, R. Surface modification of austenitic thermal spray coatings by low-temperature carburization. In Proceedings of the Conference: International Thermal Spray Conference \& Exposition 2011, Hamburg, Germany, 27-29 September 2011. Available online: www.researchgate.net/publication/320323004 (accessed on 1 November 2021).

33. Adachi, S.; Ueda, N. Formation of S-phase layer on plasma sprayed AISI 316L stainless steel coating by plasma nitriding at low temperature. Thin Solid Film. 2012, 523, 11-14. [CrossRef]

34. Adachi, S.; Ueda, N. Formation of expanded austenite on a cold-sprayed AISI 316L coating by low-temperature plasma nitriding. J. Therm. Spray Technol. 2015, 24, 1399-1407. [CrossRef]

35. Adachi, S.; Ueda, N. Wear and Corrosion Properties of cold-sprayed AISI 316L coatings treated by combined plasma carburizing and nitriding at low temperature. Coatings 2018, 8, 456. [CrossRef]

36. Lindner, T.; Mehner, T.; Lampke, T. Surface modification of austenitic thermal-spray coatings by low-temperature nitrocarburizing. IOP Conf. Ser. Mater. Sci. Eng. 2016, 118, 012008. [CrossRef]

37. Lindner, T.; Kutschmann, P.; Löbel, M.; Lampke, T. Hardening of HVOF-sprayed austenitic stainless-steel coatings by gas nitriding. Coatings 2018, 8, 348. [CrossRef]

38. Kutschmann, P.; Lindner, T.; Börner, K.; Reese, U.; Lampke, T. Effect of adjusted gas nitriding parameters on microstructure and wear resistance of HVOF-sprayed AISI 316L coatings. Materials 2019, 12, 1760. [CrossRef] [PubMed]

39. Adachi, S.; Egawa, M.; Yamaguchi, T.; Ueda, N. Low-Temperature Plasma Nitriding for Austenitic Stainless Steel Layers with Various Nickel Contents Fabricated via Direct Laser Metal Deposition. Coatings 2020, 10, 365. [CrossRef]

40. Godec, M.; Donik, Č.; Kocijan, A.; Podgornik, B.; Skobir Balantič, D.A. Effect of post-treated low-temperature plasma nitriding on the wear and corrosion resistance of 316L stainless steel manufactured by laser powder-bed fusion. Addit. Manuf. 2020, 32, 101000-101008. [CrossRef]

41. Lindner, T.; Löbel, M.; Lampke, T. Phase Stability and Microstructure Evolution of Solution-Hardened 316L Powder Feedstock for Thermal Spraying. Metals 2018, 8, 1063. [CrossRef]

42. Löbel, M.; Lindner, T.; Hunger, R.; Berger, R.; Lampke, T. Precipitation hardening of the HVOF sprayed single-phase high-entropy alloy $\mathrm{CrFeCoNi}$. Coatings 2020, 10, 701. [CrossRef]

43. Lindner, T.; Löbel, M.; Hunger, R.; Berger, R.; Lampke, T. Boriding of HVOF-sprayed Inconel 625 coatings. Surf. Coat. Technol. 2020, 404, 126456. [CrossRef]

44. Karakaş, M.S.; Günen, A.; Kanca, E.; Yilmaz, E. Boride layer growth kinetics of AISI H13 steel borided with nano-sized powders. Arch. Metall. Mater. 2018, 63, 1. [CrossRef]

45. Chaliampalias, D.; Vourlias, G.; Pavlidou, E.; Skolianos, S.; Chrissafis, K.; Stergioudis, G. Comparative examination of the microstructure and high temperature oxidation performance of NiCrBSi flame sprayed and pack cementation coatings. Appl. Surf. Sci. 2009, 255, 3605-3612. [CrossRef] 